\title{
Açlık, Ramazan Ayı ve Egzersiz
}

\author{
M. Savaş Torlak ${ }^{* 1}$, Serap Ekinci Torlak ${ }^{2}$ \\ ${ }^{1}$ KTO Karatay Üniversitesi SMYO Fizyoterapi Bölümü, Konya \\ ${ }^{2}$ Konya Numune Hastanesi, Konya
}

$\ddot{O} \mathbf{z}$

Gece boyunca 8-10 saat süreyle aç kalmak çoğu insan için normaldir. Açlık, koordineli bir dizi metabolik değişiklik ile karakterizedir, endojen karbonhidratı koruyan ve enerji kaynağı olarak yağ kullanımını artıran bir durumdur. Endojen karbonhidrat kullanımı Yayın Bilgisi Gönderi Tarihi:24.11.2017 Kabul Tarihi:29.12.2017 sınırlanırken, amino asitlerden, gliserolden ve keton cisimciklerinden glikoneojenez Online Yayın Tarihi: 29.12.2017 yoluyla karbonhidrat yapımı artış gösterir. Birçok kişi dini veya kültürel sebeplerden dolayı periyodik olarak aç kalmaktadır. Ramazan, İslam dininde 30 gün boyunca gündüz saatlerinde yiyecek ve içeceğin yasak olduğu bir açlık durumudur. Ramazan gibi aralıklı açlık durumunun, sedanter nüfusun genel beslenmesi ve fizyolojik cevapları üzerinde küçük bir etkisi bulunur. Gıda alımı gece ve sabaha yakın zamanda gerçekleşir. Vücut kitlesi genel olarak değişmez, toplam enerji alımı kabaca sabit kalır ve protein, karbonhidrat, yağ tüketiminde küçük değişiklikler görülür. Ancak uygun beslenme desteğinin eksikliği egzersize adaptasyonu azaltır ve yarışmalara hazırlık sürecini bozar. Ağır bir egzersiz sonrası iyileşme süreci gıda ve sıvı alımına bağlıdır. Bu derleme, Açlık, Ramazan ayının egzersiz performansı üzerine etkilerini bilimsel veriler 1şı̆̆ında incelemeye çalışacaktır.

Anahtar kelimeler:

Açlik,

egzersiz,

Ramazan

\section{Hunger, Ramadan and Exercise}

\begin{abstract}
Going hungry for a period of 8-10 hours at night is normal for most people. Hunger is characterized by a coordinated series of metabolic changes; it is a situation that preserves endogenous carbohydrate and increases the use of fat as a source of energy. While the consumption of endogenous carbohydrate becomes restricted, the production of carbohydrate from amino acids, glycerol and ketone bodies through gluconeogenesis increases. Many people periodically fast for religious or cultural reasons. Ramadan is a state of fasting in Islam when it is forbidden to eat and drink during daylight hours for 30 days. A state of intermittent fasting such as Ramadan has a slight effect on the general nutrition and physiological responses of the sedentary population. Food intake occurs at night and close to the morning. The body mass generally remains the same, the total energy intake roughly remains stable, and small changes are observed in the consumption of protein, carbohydrate and fat. Nevertheless, the lack of suitable nutritional support decreases the adaptation to exercising and disrupts the process of preparation for competitions. The process of recovery after heavy exercising depends on the food and liquid intake. This compilation aims to examine the effects of the month of Ramadan on exercising performance in the light of scientific data.
\end{abstract}

* Sorumlu yazar: E-posta adresi: mustafa.savas.torlak@karatay.edu.tr, +90 5373660138 


\section{GİRIŞ}

Açlık, sıvı ve gıda alımının yokluğu olarak tanımlanabilir. Açlığın ilk safhası ince bağırsak tarafından son yenen yemeğin tamamen emilmesidir. $\mathrm{Bu}$ süre, yiyeceğin türüne ve büyüklügüne bağlıdır fakat genel olarak 3-4 saat ya da en fazla 7-8 saat arasındadır (Maughan et al., 2010). Açlığın erken safhasında karaciğerdeki glikojen depoları hidrolize olur ve dolaşıma glikoz salınır böylece kan glikozu sabit tutulur. Kan glikozu düşmeye başladığ zaman, glukagon sentezi artar, dolayısıyla insülin- glukagon oranı değişir ve hızla glikojen depoları boşalır. Bu depo 10-18 saatlik açlık için yeterlidir. Karaciğer, yaklaşık 60 gram glikojen depolar. Açlığın erken safhasında glikojen depolarından her saat ortalama 4 gram glikoz salınır (Maughan et al., 2010). Açlık devam ederse karaciğerde glikoz sentezi başlar. Bunun için amino asitlerin karbon iskeletleri, pirüvat ve laktat kullanılır. Glikoneojenez son yemekten 4-6 saat ve glikojen deposu tamamen boşaldıktan sonra başlar (Aksoy, 2000). Açlık daha da uzun sürerse glikozun kullanımı azalır ve enerji için yağların kullanımı artar. $\mathrm{Bu}$ etki dokulardaki karbonhidrat depolarının sınırlı olmasından dolayıdır ve bu etki sayesinde glikoz beynin ve eritrositlerin faaliyeti için kullanılır (Maughan et al., 2010).

Açlığın en önemli yanıtı yağ dokusundaki trigliserit depolarının hidrolizidir. Böylece plazmada yağ asidi miktarı önemli ölçüde artar ve kaslar enerji olarak yağ asitlerini kullanır. Adrenalin ve noradrenalin adipoz dokudaki sempatik sinir uçlarından salınır ve bunlar hormona duyarlı lipaz için önemlidirler. Trigliserit hidroliziyle sağlanan yağ asitleri albümine bağlanarak gerekli dokularda yıkılmak üzere taşınır (Aksoy, 2000). Aynı zamanda adipoz hücrelerinden gliserol salınımında artış olur ve gliserol karaciğerde glikoneojenez ile glikoza çevrilerek vücuttaki karbonhidrat havuzuna katkıda bulunur (Maughan et al., 2010). Karaciğer, keton cisimciklerini sentezleyerek periferal dokulara enerji kaynağı olarak salabilir. Keton cisimcikleri sentezi, yă̆ asit metabolizması sonucu artan asetil CoA konsantrasyonuyla üretilir. En önemli sentez, açlığın ilk günü olur (Aksoy, 2000).

Yağ depolarının mobilizasyonu ve karaciğerdeki glikoneojenez bir takım hormonal değişikliğe de sebep olur. Plazma insülin konsantrasyonu azalır, dolaşımdaki glukagon hormonu, katekolaminler, büyüme hormonu, kortikostreoidler ve tiroid uyarıcı hormon (TSH) konsantrasyonu artar (Maughan et al., 2010).

Açlığın ilk birkaç saati dışında en büyük etki, dokuda yağ ve proteinlerin gittikçe azalmasıdır. Vücuttaki bütün yağ depoları açlık devam ettiği sürece kesintisiz olarak boşalır. Protein azalması ise üç aşamada gerçekleşir. İlk olarak hızlı bir azalma, sonra yavaş azalma ve nihayet ölümden kısa bir süre önce tekrar hızlı bir azalma gözlenir. Başlangıçtaki hızlı azalma proteinin glikoza çevrilmesi ve beyin tarafından glikoz metabolizması için kullanılmasından kaynaklanır (Guyton \& Hall, 2007). Protein depoları tükenince geri kalan protein kolaylıkla mobilize olmaz ve glikoneojenez hızı azalır. Glikozun azalması yağ kullanımının artmasına sebep olur ve yağ yıkım ürünlerinden bir kısmının keton cisimciklerine dönüşümü gerçekleşir ve bu durum ketoza yol açar (Guyton \& Hall, 2007).

Sonunda yağ depolarının tamamen boşaldığı ve enerji kaynağının yalnızca proteinlerden ibaret olduğu bir durum ortaya çıkar. Bu durumda protein yedekleri yeniden hızla azalmaya 
başlar. Proteinler, hücresel işlevlerin sürdürülebilmesi için gerekli olduğundan, vücut proteinleri normal düzeyin yarısına geldiğinde ölüm kaçınılmaz olur (Guyton \& Hall, 2007).

Açlık sürecini özetlersek, kısa açlığı 72 saat altı, uzun açlığ 72 saat üstü olarak tanımlamak ve 72 saatin kritik önemini vurgulamak önemlidir (Barendregt et al., 2008).

İlk 24 saatte karaciğerdeki glikojen depoları kısa süreli kullanılır. Kaslardaki glikojen, sadece kas dokusuna glikoz sağlar (Kraft et al., 2005). 6-12 saatlik açlıkta insülin düzeyi düşmeye başlar. Kan glikozunu yükseltmek için karaciğer ve böbrekte glikoneogenez uyarılır. İnsülinin düşmesi ile çevresel dokularda glikoz kullanımı azalır ve sadece glikozu kullanabilen santral sinir sistemine kaynak ayrılmış olur (Barendregt et al., 2008). İlk 72 saatte beyin, renal medulla ve eritrositler öncelikli olarak glikoz kullanır (Kraft et al., 2005). Çevre dokular enerji kaynağı olarak glikoz yerine yă̆ asitlerini kullanır. Glikojen depoları boşaldığında çevresel dokulara ait proteinler yıkılmaya başlar. 72 saat sonrasında, glikoz sentezi öncelikle yağ asitlerinden ve sonra proteinlerden sağlanır. Sıvı alımı yok ise dehidratasyon nedeniyle kişi ölür. Yeterli sıvı ve elektrolit desteği ile kişi birkaç ay daha yaşayabilir (Barendregt et al., 2008; Mcdonald \& Smith, 2001).

En yaygın olarak üzerinde çalışılan üç tip açlık şekli vardır: 1. Kalori kısıtlaması 2.Diyet kısıtlaması 3. Aralıklı aç kalma (Treponowski \& Bloomer, 2010).

Kalori kısıtlaması, besin tüketiminin kilokalori (kcal) cinsinden istenildiği kadar (genellikle \% 20-40) azaltılmasıdır. Kalori kısıtlamasının sağlıklı ve uzun yaşamayı desteklediği, köpeklerde, meyve sineklerinde, iplik kurtlarında, kemirgenlerde ve maymunlarda gösterilmiştir (Splinder, 2010). Buna ek olarak, kalori kısıtlaması, otoimmun hastalıklar, ateroskleroz, kanser, diyabet, böbrek ve akciğer hastalıklarının başlamasını geciktirebilir (İmai, 2009; Vaguero \& Reinberg, 2009).

Diyet kısıtlaması ise toplam kilokalori alımını kısıtlamadan, belli yiyecek gruplarını yememek olarak özetlenebilir. Örneğin Yunan Ortodoks Hıristiyanları dini inançları gereği 40 gün boyunca süt ürünleri, yumurta ve etten uzak dururlar. Bu dönemde ayrıca Çarşamba ve Cuma günleri balık ve zeytinyağı da yasaktır. Ayrıca Hıristiyanlarda popüler olan ve aziz Daniel'ın İncil'deki hikayesine dayanan Daniel orucunda 21 gün boyunca alınan gidalar meyve, sebze, kepekli tahıllar, yağ, baklagiller ve fındık ile sınırlıdır (Treponowski \& Bloomer, 2010).

Aralıklı aç kalma, 24 saatlik periyot içerisinde aç kalma ve tok olma durumlarını içerir. Su her zaman serbesttir. Hayvanlar üzerinde yapılan çalışmalar aralıklı açlığın kardiyovasküler rahatsılıklar, böbrek rahatsızlıkları, kanser ve diyabet gibi hastalıklardan koruyarak yaşam ömrünü uzattı̆̆ 1 gösterilmiştir (Matson \& Wan, 2005; Varady \& Hellerstein, 2007). Ramazan ayında tutulan oruç aralıklı aç kalma durumuna benzemektedir. Ancak sahurdan iftara kadar su içmek de yasaktır (Treponowski \& Bloomer, 2010). Uzun süre gıda alınmaması hem sağlığı hem de performansı olumsuz yönde etkiler (Maughan et al., 2010). 


\section{Klinik Tablo}

Açlığın erken dönemlerinde, hipoglisemiye sempatik sistemin cevabıyla kan basıncı yükselebilir ve taşikardi gelişebilir. Açlık ilerledikçe kan basıncı düşer, kardiyak pompa gücü ve atım hacmi azalır. Öncesinde kardiyak sorunu olmayan bireylerde bile uzun süreli açlıkta; kapak fonksiyon bozukluğu, perikardiyal efüzyon, QT uzaması, ventriküler fibrilasyon ve ani kalp ölümü gerçekleşebilir (Altun ve ark., 2004). Uzun süreli malnütrasyon metabolizmayı \%20-30 kadar azaltabilir. (Guyton \& Hall, 2007).

Hem kas hem de yağ dokusu kaybı nedeniyle ekstremite, yüz, toraks ve abdomende zayıflık belirgindir. İlk hafta genellikle \%5-10 kilo kaybı görülür. Sonra bu kayıp devam eder ve \%35-50’lere kadar varabilir. Deri soğuk, soluk ve kurudur. Böbrek fonksiyonları yavaşlar. Böbreğe gelen kan miktarı ve kreatin klirensi azalmaya başlar. Yeterli sıvı alınmaz ise dehidratasyon belirtileri şiddetlenir (Altun ve ark., 2004; Barendregt et al., 2008; Mcdonald \& Smith, 2001).

Hipovoleminin aldesteron sekresyonunu sekonder olarak uyarmasıyla su ve sodyum emilimi sağlanmaya çalışılırken, potasyum kaybı belirginleşir. Bir yandan volüm azalmasıyla birlikte antidiüretik hormon ve atriyal natriüretik peptid uyarılır ve natriürez ile sodyum kaybı belirginleşir. Kişi susuzluk hissini kaybeder. Gastrointestinal sistem, lenfatik sistem ve pankreasta atrofiler başlar. Açlık hissi ve karın ağrıları kaybolur. Hem hücresel hem de hümoral immünite bozulur ve infeksiyonlara duyarlılık artar, vücut direnci azalır ve sepsis tablosu gelişebilir (Altun ve ark., 2004; Barendregt et al., 2008; Mcdonald \& Smith, 2001).

\section{Yeniden Beslenme Sendromu}

Yeniden beslenme sendromu, uzun süreli ve şiddetli açlığın ardından hızlı beslenmeyle ortaya çıkan ve yaşamı tehdit eden kardiyovasküler, pulmoner, renal, nöromusküler, metabolik ve hematolojik özellikleri olan ağır bir tablodur (Gariballa, 2008; Tresley \& Sheean, 2008).

Yeniden beslenmede sorun karbonhidratın alınması ile başlamaktadır. Glikozun yükselmesiyle insülin yükselir. Glikozun hücre içine girişiyle fosfat, magnezyum ve potasyum yer değiştirir. Karbonhidratların hızlı alımıyla su ve sodyum atılımı azalır. Ekstrasellüler sıvı miktarı artar, ödem gelişir. Hipofosfatemi bu sendromda karakteristiktir ve kardiyak aritmilere, kalp yetmezliğine, rabdomiyolize ve konfüzyona yol açar (Gariballa, 2008; Tresley \& Sheean, 2008).

Vücut ağırlığının \%10'undan fazlasını kaybeden veya ideal vücut ağırlığının \%70'inin altında olan kişiler yeniden beslenme sendromu açısından risk altındadırlar. $\mathrm{Bu}$ sendromu engelleyecek üstünlüğü kesinleşmiş tek bir reçete yoktur. "Düşük başla ve yavaş devam et'" kuralı önerilmektedir (Tresley \& Shean, 2008). Günlük en fazla 1 lt sıvıyla başlanmalı ve günlük kilo alımı 200 gr'ın altında olacak şekilde planlanmalıdır (Tresley \& Shean, 2008). 


\section{Açlık ve Egzersiz}

Gerekenden daha az sıvı, besin ve enerji alımı vücut 1sısının ayarlanmasını, substrat kullanımını, egzersiz kapasitesini, egzersizden sonra toparlanmayı ve antreman yanıtını önemli ölçüde etkiler (Mcardle et al., 2007).

Elit bir sporcunun antreman programı, her gün bir veya daha fazla antremanı içerir. Antreman sonrası toparlanma ve homeostasizin yeniden düzenlenmesi karmaşık bir süreçtir. $\mathrm{Bu}$ süreç, kas ve karaciğer glikojen depolarının tekrar dolumu, terlemeyle kaybolan sıvı ve elektrolit kaybının yerine konması, tamir ve adaptasyon için protein sentezi, sporcunun sağlıklı kalabilmesi için immün ve antioksidan sistemlerin düzgün çalışmasını içerir. Her antreman sonunda alınan gidalar bu süreci etkiler (Burke, 2010). Özellikle yeterli miktarda karbonhidrat, tuz ve su alımı, sporcularda egzersiz sırasında oluşan dehidratasyon, hiperhidrasyon ve sıcaklığa bağlı rahatsızlıkları ve yorgunluğu azaltır. Amino asit ve gliserol alımı egzersiz sırasında sporcuya faydalı değildir (Coyle, 2004).

Açlık, kan glikoz konsantrasyonu üzerinde hızlı fizyolojik adaptasyonlara sebep olur, aynı zamanda iskelet kası gibi diğer dokuları destekleyici alternatif enerji kaynaklarını uyarır böylece açlık dönemi boyunca yapılan fiziksel aktiviteye olanak sağlanır (Stannard, 2003). Örneğin dayanıklılık egzersizi sonucunda karbonhidrat depoları tükenir. Egzersiz uzun sürerse yağların mobilizasyonu artırılarak kas kasılması için kullanılır, böylece beynin faaliyeti için yeterli karbonhidrat ayrılmış olur (Stannard, 2003).

Ekzojen gıda alımı dayanıklılık egzersizinde akut metabolik cevapların düzenlenmesinde önemli rol oynar. Örneğin, karbonhidrat alımı kas kasılmasına enerji sağlayan metabolik substrat havuzuna kan şekerinin geçişini uyarır ve yağ oksidasyonunu inhibe eder (Cox et al, 2010). Aksine yüksek yağlı yiyecekler, yağ oksidasyonuyla enerji üretimini uyarır karbonhidrat kullanımını baskılar (Burke, 2000).

Orta düzey bir egzersiz sonrası kas glikojeninin yenilenmesi dışarıdan alınan karbonhidrata bağlıdır. Ortalama yenilenme hızı saatte 5-6 mmol kadardır ve depoların tamamen dolması bir günü alır (Burke, 2010). Ağır bir egzersizi takiben glikojen depoları tamamen tükenir, yaklaşık bir saat süren nispeten hızlı bir yenilemeden sonra insüline bağımlı birkaç gün süren daha yavaş bir aşama bu süreci takip eder (Ivy \& Kuo, 1998).

Aç karnına yapılan egzersizde dolaşımda düşük insülin seviyesi ve yüksek plazma epinefrin seviyesi görülürken (Arkinstall et al., 2001; De Bock et al., 2005; Febbraio et al., 2000), adipoz dokudaki lipolizde ve periferal yağ oksidasyonunda artış olur (Horowitz et al, 1997).

Tokluk durumunda yapılan benzer egzersize göre açlık durumunda yapılan egzersizde tip 1 liflerinde kas içi lipitlerinde y1kım (De Bock et al., 2005) ve tip 2 liflerinde glikojen depolarının azalması daha fazladır (De Bock et al., 2007). Ayrıca 6 hafta boyunca açken yapılan dayanıklılık egzersizinde kasta yağ asidi bağlayıcı protein miktarında artış görülmüş̧ür (De Bock et al., 2008). Bu bulgulara göre açlık durumunda yapılan egzersizde kas hücreleri yağ oksidasyonu yoluyla enerji üretmektedirler. 
Açken yapılan direnç egzersizi ve aerobik egzersizin sağlıklı erkeklerde gıda alımını ve iştah duygusunu artıran ghrelin ve nöropeptit $\mathrm{Y}$ hormonlarının dolaşımda artmasına neden olduğu bildirilmiştir (Broom et al., 2008). Yine yapılan başka bir çalışmada (Bozinovski et al., 2009) 9-14 yaşları arasındaki kız ve erkek çocuklarında egzersizin ortalama iştahı, yeme isteğini ve açlığı artırdığı gözlenmiştir. Sonuç olarak, açlık durumunda yapılan egzersiz, glikojen yıkım kapasitesini azaltırken, yağ oksidasyonunu uyarır (De bock et al., 2007).

\section{Ramazan ve Egzersiz}

Ramazanda, gıda ve sıvı alım zamanları değiştiği ve aynı zamanda uyku süresi de azaldığı için günlük aktiviteler, zihinsel ve fiziksel performans etkilenebilir (Waterhouse, 2010). Sporcuların Ramazan ayında performanslarının nasıl etkilendiği çeşitli çalışmalarda araştırma konusu olmuştur. Örneğin futbolcularda yapılan bir çalışmada aerobik kapasite, dayanıklılık ve zıplama yeteneğinde azalma görülürken, hız ve çevikliklerinde değişiklik gözlenmemiştir (Meckel, 2008). Futbolcular üzerinde yapılan başka bir çalışmada ise hız, güç, çeviklik, dayanıklılık ve top sürme becerilerinde herhangi bir değişiklik bulunmamıştır (Kirkendall, 2008). Buna ek olarak, Ramazan ayında kişisel performansın azaldığı (Zerguini et al., 2007) veya gerekli performansı yakalamak için daha fazla antreman yapıldığı gözlenmiştir (Zerguini et al., 2008). Performanstaki bu azalmanın Ramazan ayının hemen sonrasında düzeldiği gösterilmiştir (Wilson et al., 2009).

Ramazan ayında farklı spor dallarında performans kaybı gözlense de, egzersiz ile ilişkili fizyolojik değişkenlerde sistematik olarak bir düşüş olup olmadığı belirsizdir. Örneğin, Ramazan ayında sedanter katılımcilar VO2max'larının \%70'inde egzersiz yaptıklarında herhangi bir performans kaybı gözlenmemiş, fakat Ramazan ayının sonunda sistolik kan basıncında artış gözlenmiştir (Ramadan, 2002). Siddugui ve arkadaşlarının (2005) yaptığı başka bir çalışmada sağlıklı katılımcıların Ramazan ayı boyunca vital kapasitelerinde, zorlu ekspirasyon hacimlerinde, maksimum istemli solunum hacimlerinde herhangi bir farklılık bulunmamıştır.

Ramazan ayında performanstaki azalmanın çeşitli nedenleri olabilir. Pratik olarak sorunlar, açlıktan dolayı kas ve karaciğer glikojen depolarının ilerleyici olarak azalması, sıv1 rezervlerinin düşmesi ve kan glikoz seviyesinin azalması olabilir (Shephard, 2012). Uzun süreli dehidratasyon, anaerobik ve dayanıklılık gerektiren aktivitelerde gerekli olan metabolitlerin kaybına neden olur, düşük kan glikoz seviyesi beyin faaliyetlerini etkileyerek kişinin ruh halinin bozulmasına ve takımla yapılan spor dallarında ekip üyeleri arasında koordinasyon kaybına neden olabilir (Shephard, 2012).

\section{Ramazan ve Sirkadiyan Ritim}

Ramazan ayında, sıvı ve gıda alım zamanları değiştiği gibi, uyanık kalma süresi artar ve uyku kaybı nedeniyle yorgunluk gelişir. Bu değişkenler sirkadiyan ritmi etkiler (Waterhouse et al, 2008). 
Sirkadiyan ritim değişikliğine bağlı olarak, melatonin salgılanmasında azalma ve kortizol seviyesinde artış gözlenir (Bahammam, 2006). Uyku süresinin azalması performansı olumsuz yönde etkileyebilir. Malezyalı genç sporcuların Ramazan süresince performanslarının \%29,3 azaldığı ve \%66,6 oranında da uyku sorunu çektikleri gözlenmiştir (Singh et al., 2011). Uyku süresinin azalmasının kas aktivitesi üzerinde direkt olarak küçük bir etkisi olduğu ancak mental performans, koordinasyon ve motivasyonu değiştirerek indirekt yoldan fiziksel performansı etkilediği gösterilmiştir (Reily \& Waterhouse, 2009).

Açlık, uyanıklık ve ruh hali üzerine negatif etkiler oluşturabilir. Rocky ve arkadaşları (2004) Ramazan ayı süresince yaptıkları çalışmada, katılımcıların saat 9:00'da ve 16:00'da uyanıklık durumlarının azaldığını saat 23:00'de ise arttığını göstermişlerdir. Bunun sebebinin azalmış enerji alımı ve uyku kaybı olduğu sonucuna varmışlardır. Tian ve arkadaşları (2011) 18 genç erkek sporcuda serebral fonksiyonun çeşitli yönlerini incelemişler, Ramazan boyunca 9:00'da psikomotor performans ve uyanıklık halinin arttığını ancak kan glikoz seviyesinin düşmesiyle 16:00'de sözel öğrenme ve belleğin bozulduğunu göstermişlerdir. Aziz ve arkadaşları (2010) ise Ramazan sırasında uyku durumunda bir değişiklik bulamamışlar ancak gün içerisinde dikkat ve konsantrasyonun azaldığını göstermişlerdir. Yemek yeme, özellikle yüksek karbonhidratlı yiyecekler uyanıklık ve ruh halini korur (Bellisle et al., 1997). Gıda yoksunluğundan sonra sıçanlar yüksek triptofan içeren protein diyetiyle beslendiklerinde bozulan uyku düzeninin tekrar düzeldiği görülmüştür (Minet-Ringuet et al., 2004). Bu sebeplerden dolayı Ramazan boyunca gida ve siv1 kisıtlamasının ruh hali ve zihinsel performans üzerine olumsuz etkileri olabilir. Kortizol ve testesteron, normalde sabahleyin uyanma vakti civarında en yüksek seviyededir. Bogdan ve arkadaşları (2001) Ramazan ayında bu hormonların her ikisinin de salgılanma zamanlarında bir kayma olduğunu göstermişlerdir, ayrıca çalışmada prolaktin salgısı artmış, melatonin salgısı azalmış ve yorgunluk artışı görülmüştür. Ramazan ayında günün erken ve geç saatlerinde yemek yemenin serum leptin pik seviyesinin en az 5 saat gecikmesine neden olduğu gösterilmiştir (Bogdan et al., 2005). Özetle, Ramazan ayında gıda ve sıvı alımında ve uyku düzenindeki değişiklikler performansı olumsuz olarak etkileyebilir.

\section{Ramazan ve Dehidratasyon}

Su, insan yaşamı için oksijenden sonra gelen en önemli ögedir. İnsan besin almadan haftalarca canlılı̆̆ını sürdürmesine rağmen, susuz ancak birkaç gün yaşayabilir (Baysal, 2004). Pratik olarak, soğukta $\left(5-10{ }^{\circ} \mathrm{C}\right)$ veya sicakta $\left(21-22{ }^{\circ} \mathrm{C}\right)$ vücut sivisının \% 2 azalması egzersiz performansını değiştirmez (Coyle, 2003).

Ramazan ayı gibi kutsal aylarda tutulan oruç sırasında gıda alımının kısıtlanmasına ek olarak sıvı alımı da kısıtlanmaktadır. Ramazan ayının başlamasıyla genel vücut sıvısının korunmasında sorunlar görülebilir (Stannard \& Thompson, 2008). Ramazan ayında plazma volümünün azaldığ1, hematokrit, hemoglobin ve plazma elektrolit konsantrasyonunun arttığ gösterilmiştir (Ramadan et al., 1999). Bununla birlikte Ramazan ayında, fiziksel olarak aktif bireylerde istirahatte bile serum elektrolit konsantrasyonlarının biraz artış gösterdiği bulunmuştur (Trabelsi, 2011). Maughan ve arkadaşları (2008), Ramazan ayı sırasında oruç 
tutan futbolcuların tuz alımında azalma olduğunu, kontrol grubunda ise hafif artış olduğunu göstermişlerdir. Trabelsi ve arkadaşları (2011) 12 rugby oyuncusunda yaptıkları çalışmada Ramazan öncesine göre Ramazan sonunda hematokrit değerlerinin oynanan maçın hemen sonrasında \%1,4 arttığını göstermişlerdir. Ciddi dehidratasyon, sıcak ve nemli havada oynanan takım oyunlarında ve dayanıklılık ve ultra-dayanıklılık gerektiren yarışmalarda görülür. Genç futbolcuların Ramazan ayında bir maç sırasında ortalama 1,4 lt sıvı kaybettikleri görülmüştür (Shirreffs \& Maughan, 2008). Bununla birlikte, Ramazanda günlük sıvı alımı fazla değişmez ve hematokrit veya hemoglobin değerleri küçük miktarlarda değişebilir (Maughan et al., 2008). Sporcularda sıvı kaybını önlemek için, iftardan yatma zamanına kadar olan sürede saatte $600 \mathrm{ml}$ kadar sıvı ve sahurda da ilave olarak 1 lt sıv1 almaları önerilmektedir (Shephard, 2012).

\section{Ramazan ve Açlık Kan Glikozu}

Açlık ve tokluk hislerinin düzenlenmesinde kan şekerinin önemli rolü vardır. Kan şekerinin düşmesiyle pankreastan glukagon, adrenal bezden de epinefrin kana salınır. Bu hormonlar karaciğerde glikojenin glikoza yıkımını sağlar, böylece kan glikoz düzeyi yükselir. Kan şekeri yükseldiğinde ise insülin salgısı artar, karaciğer ve kaslarda glikoz glikojene çevrilir ve kan glikozu düşer (Baysal, 2002).

Sporcu olmayan bireylerde Ramazan ayı süresince istirahat kan glikozu çok fazla etkilenmez ve normal klinik sınırlar içerisinde kalır (Mansi, 2007). Cezayirli gençlerde Ramazan ayında yapılan bir çalışmada açlık kan glikozunda herhangi bir değişiklik bulanamamıştır (Senhadji et al., 2009). Kassab ve arkadaşları (2003) Ramazan ayında serum leptin seviyelerinin obez ve obez olmayan bireylerde sırasıyla \% 37 ve \% 39 oranında arttığını göstermişler, ayrıca serum leptin seviyesinin ve insülin düzeyinin orantılı olarak arttığı ve bunun da insülin hormonunun leptin salınımını düzenlemesinden kaynaklandığını öne sürmüşlerdir. Özetle, Ramazanda sporcu yeteri kadar besin ve sıvı alırsa açlık kan glikozunda küçük değiş̧iklikler olur ve atletik performans etkilenmez.

\section{Ramazan ve Anaerobik Aktivite}

Ani şiddetli aktivite sırasında, anaerobik enerji kullanımı başlıca glikolizden sağlanır. Bunlar: (1) kas hücrelerinde mevcut bulunan ATP, (2) hücrelerdeki fosfokreatin ve (3) glikojenin laktik aside glikolitik yıkımından serbestlenen anaerobik enerjidir (Guyton \& Hall, 2007). Ramazan ayı gibi aralıklı açlık durumunda, eğer sporcu uykusuna, antreman programına ve yediklerine dikkat ederse anaerobik güç veya kapasitede çok az değişiklik gözlenir. Souissi ve arkadaşları (2007) fiziksel olarak sağlıklı 12 erkek öğrencinin katıldı̆̆ı bir çalışmada Wingate testi ile katılımcıların ortalama ve maksimum güçlerini Ramazan ayı süresince değerlendirmişlerdir. Antreman dönemi boyunca normal fiziksel aktivite serbest bırakılmıştır ve katılımcıların uykusuzluğuna yol açabilecek maddeler yasaklanmıştır. Toplam enerji alımı ve önemli besin maddelerinin tüketiminde Ramazan ayı boyunca bir değişiklik gözlenmemiştir. Ramazan öncesi tüm katılımcılar ortalama 8 saat uyurken Ramazan ayında bu süre 5.5 saate inmiştir. Çalışmanın sonucunda özellikle öğleden sonra yapılan çalışmada belirgin olarak güçte azalma ve yorgunlukta artma gözlenmiş bu azalmanın 
diyet kısıtlamasının toplam etkisi olarak kas glikojen depolarındaki azalmaya bağlı olduğu düşünülmüş ancak gıda alımında bir eksiklik olmadığı için bunun mümkün olmadığ1 sonucuna varılmıştır.

Karlı ve arkadaşları (2007) Ramazan ayında, uyguladıkları Wingate testinde öğleden sonraki ölçümlerde anaerobik güç veya anaerobik kapasitede herhangi bir değişiklik bulamamışlardır. Chaouachi ve arkadaşlarının çalışmasında (2009), uluslararası seviyedeki 15 genç judocunun Ramazan ayında 5, 10 ve 30 metrelik sürat koşusu performansını değerlendirilmiş, gece yenilen yemeğe hiçbir kısıtlama getirilmemiş ve enerji alımı sabit tutulmuş ve sonuç olarak performansta herhangi bir değişiklik gözlenmemiştir.

Kirkendall ve arkadaşları (2008) 85 genç futbolcu üzerinde yaptıkları çalışmada, Ramazan ayı süresince futbolcuların bir kısmını sabahleyin bir kısmını da öğleden sonra yedi kez 30 metrelik sürat koşusu yaptırmışlar ve performansı değerlendirmişlerdir. Sporcularda herhangi bir değişiklik gözlenmemiştir. Zerguini ve arkadaşlarının (2007) yaptığı çalışmada, Ramazan ayı sırasında Cezayirli futbolcuların hızlarında ve ani koşularında belirgin bir azalma gözlenmesine rağmen bunun futbolcuların aynı zamanda normal fiziksel aktivitelerini de azaltmasından dolayı olduğu görülmüştür. Yapılan bazı çalışmalarda, Ramazan ayı sırasında dikey sıçrama, çömelerek sıçrama veya hareketli sıçrama skorlarında herhangi bir değişiklik gözlenmemiştir (Chaouachi et al., 2009; Kirkendall et al., 2008; Zerguini et al., 2007).

\section{Ramazan ve Aerobik Aktivite}

Kas performansının bir ölçüsü dayanıklılıktır. Bu büyük ölçüde, kasın beslenmesine ve kasta egzersizden önce depo edilen glikojen miktarına bağlıdır. Karbonhidrattan zengin bir diyetle beslenen kişide kaslardaki glikojen deposu, karışı ya da yağdan zengin diyetle beslenen kişiye göre çok daha büyüktür. Bu nedenle dayanıklılık karbonhidrattan zengin diyetle çok $\operatorname{artar}$ (Guyton \& Hall, 2007).

Kastaki glikojen deposunun boşalmasından sonra, yenilenmesi basit bir olay değildir. Kasın fosfojen ve glikojen-laktik asit sistemlerinin yenilenmesi için saniyeler, dakikalar ve saatler gerektirdiği halde, kas glikojeninin yerine konması günlerce sürebilir. Tüketici yarışlardan önce atletin yüksek karbonhidrat diyeti alması çok önemlidir ve yarışmalardan 48 saat önce tüketici ağır egzersiz yapılmamalıdır (Guyton \& Hall, 2007). Bu yüzden açlıkta glikojen depoları sınırlı yenilendiğinden dolayı zayıf performans görülmektedir.

Zerguini ve arkadaşları (2007), Ramazan ayının sonunda, profesyonel futbolcuların 12 dakikalık koşu mesafesinin \%16 azaldığını tespit etmişler, bu mesafenin iki hafta sonra düzeldiğini ancak bu tür efor testlerinin kişisel motivasyona büyük oranda bağlı olduğunu bildirmişlerdir. Briswalter ve arkadaşları (2011), Ramazan ayı sırasında 9 orta mesafe koşucusu ve 9 koşucu olmayan katılımcının 5000 metre koşu performansını karşılaştırmışlardır. Ramazan ayının sonunda koşucu olmayan sporcuların 5000 metre zamanı $\% 5$ artmıştır, fakat maksimal aerobik güç veya koşu verimliliğinde değişiklik gözlenmemiştir. Meckel ve arkadaşları (2008), benzer bir çalışmada 14 ila 16 yaş aralığındaki futbolcuların 3000 metre koşu zamanlarında çok küçük bir artma (\%1) olduğunu tespit etmişlerdir. 
Chaouachi ve arkadaşları (2009), Ramazan ayında elit judocular üzerinde yaptıkları çalışmada Leger testi ile ölçtükleri maksimal oksijen tüketiminde herhangi bir farklılık bulamamışlardır. Benzer şekilde, diğer araştırmalarda da (Ramadan, 2002; Ramadan et al., 1999) Ramazan ayı sırasında submaksimal aerobik egzersiz performansında herhangi bir değişiklik bulunamamıştır.

Yo-Yo aralıklı toparlanma testi, 10 saniyelik yürüme ya da koşma ile yapılan ve aktif toparlanma dönemlerini içeren ve birey koşmayı devam ettiremeyene kadar süren bir testtir (Dupont et al., 2010). Chtouru ve arkadaşları (2011) Yo-Yo aralıklı toparlanma testi ile maksimal aerobik gücü ölçmüşler ve Ramazan ayı sırasında öğleden sonra maksimum güç ve maksimum hızın azaldığı ve yorgunluk indeksinin arttı̆̆ını tespit etmişlerdir.

Aziz ve arkadaşları (2010), Ramazan ayı süresince orta seviyede antremanlı 10 erkek katılımcıyı saat 16:00 ve 18:00 arası 30 dakika \% 65 oksijen tüketimi ile koşturmuşlar, ardından 30 dakika maksimal hızda koşturmuşlardır. On katılımcının dokuzunda performans kaybı gözlenmesine ve ortalama koşu mesafesi \% 4 azalmasına rağmen ciddi azalma yalnızca beş katılımcıda gözlenmiştir. Araştırmacılar bu azalmanın, açlığın glikojen depoları ve su dengesi üzerine etkisinden dolayı gerçekleştiğini tespit etmişlerdir. Ramazan ayında yapılan çalışmalarda, eğer sporcu gerekli besini alır ve antremanına dikkat ederse kas gücünde belirgin bir azalma görülmemektedir. Brisswalter ve arkadaşları (2011), dokuz orta mesafe koşucusunda yaptıkları çalışmada, Ramazan ayının sonunda maksimal diz ekstansiyon gücünde \%3,2 oranında küçük bir azalma gözlemişlerdir. Meckel ve arkadaşları (2008), Ramazan ayının sonunda 14 ila 16 yaşındaki futbolcuların dikey sıçrama testlerinde \%1,8'lik bir azalma bulmuşlardır ancak futbolcular Ramazan ayı sırasında antremanlarını da azaltmışlardır.

\section{TARTIŞMA - SONUÇ ve ÖNERILER}

Bazı çalışmalar Ramazan orucunun performansı düşürdüğünü belirtirken (Faye et al., 2005; Zerguini et al., 2007), diğer yandan bazı çalışmalar sportif performansı etkilemediğini öne sürmektedir (Kirkendall et al., 2008; Zerguini et al., 2008). Bu farklılıklar, Ramazan ayının denk geldiği mevsime göre yiyecek ve su kısıtlamasının süresine, performans testlerinin farklılığına veya ortam şartlarına bağlı olabilir (Fallah, 2010). Müslüman sporcular çeşitli yarışmalara katılmak için antreman yaparken oruç tutmaktan vazgeçmezler. Ancak bazı sporcular yarışma günlerinde performanslarının olumsuz etkileneceğini düşünerek oruç tutmazlar (Maughan et al., 2010).

Ramazan ayında görülen egzersiz performansındaki düşmenin altında yatan mekanizmaları açıklayan sağlam bir dayanak yoktur. Bu performans kaybı, uyku- uyanıklık durumu, gıda ve sıv1 alımı, sirkadiyan ritmdeki değişiklikler gibi birçok faktöre bağlanmaktadır (Waterhouse, 2010; Zerguini, 2008). Diğer yandan sporcunun motivasyonu, çabası, alışkanlıkları da performansı etkilemektedir (Waterhouse, 2010). Ramazan ayının atletik performans üzerine yan etkilerini azaltmak için potansiyel taktikler, yarışma zamanının değiştirilmesi, uyku bozukluğunu düzeltmek, açlık kan şekeri ve dehidratasyonu kontrol altında tutmak, ruhsal durumu düzeltmek ve antreman programını tam olarak uygulamak şeklinde özetlenebilir (Roy et al., 2011). Müslümanların, Ramazan ayında fiziksel aktivitesini azaltması 
önerilmektedir (Reilly \& Waterhouse, 2007). Eğer kişi sporcuysa, Ramazan ayında antrenörler sporcunun vücut kitle indeksini dikkatle takip etmeli ve antreman dönemlerini iyi ayarlamalıdır (Chaouachi et al., 2009). Performansı bozan ve kolaylaştıran bu faktörler göz önüne alındığında antreman zamanının atletik performans üzerinde önemli bir rolü bulunmaktadır. Sporcular genellikle antremanlarını rahatlık ve etkili olduğunundan dolayı gündüz vakti yapmayı tercih etmektedirler. Diğer yandan Ramazan ayında gündüz yapılan antremanlarda verimin düşmesi muhtemeldir (Waterhouse, 2010). Açlık sırasında oluşan eksiklikleri güneş battıktan sonraki ilk öğün iftar sırasında alınan sıvı ve gıda takviyesiyle kapatmak akşam yapılan egzersizde faydalı olabilir (Atkinson et al., 2007). Ramazan ayında olumsuz etkilerden kaçınmada yarışma zamanının değiştirilmesi basit bir tedbirdir. Sporcular sabahın erken saatlerinde ya da gece geç saatlerinde daha rekabetçidirler. Bu taktik sıklıkla arap ülkelerinde yarışmalar sırasında uygulanmaktadır ve muhtemelen uyku yoksunluğu dışındaki birçok problemin oluşmasını önlemektedir. Bununla birlikte müslüman olmayan ülkelerde düzenlenen organizasyonların yarışma saatleri bu taktiğin uygulanmasını güçleştirmektedir (Shephard, 2012).

Ramazan ayının denk geldiği mevsimde performansı etkileyebilmektedir. Ramazan, yaz aylarına denk geldiğinde uzun oruç zamanı ve hava sıcaklığı performansı olumsuz yönde etkiler. Bu durumda sporcu akşam yemeğinden hemen sonra yatmalı ve sahura kadar en az 8 saat uyumalıdır, gün içerisinde de uyunabilir. Uyku için sessiz ve karanlık bir oda seçilmeli ve Ramazan başlamadan önce sporcu uyku düzenini ayarlamalıdır (Shephard, 2012).

Fiziksel olarak aktif olan sporcular antremanlarda ve yarışmalarda fiziksel performans göstermek için makro ve mikro bütün gıda maddelerinden dengeli bir şekilde tüketmelidir. Sporcunun günlük diyetinde, kilogram başına 6-10 gr karbonhidrat, 1.2- 1.7 gr protein ve toplam alınan enerjinin \% $20-35$ arasında yağ bulunmalıdır (Rodriguez et al., 2009).

Genel olarak Ramazanda yağ, karbonhidrat ve protein metabolizmasında küçük değişiklikler gözlenir (Chaouachi et al., 2008). Ancak, Ramazan öncesinde antremandan gerekli verimi almak için uygun bir beslenme modeli seçilmelidir (Hawley et al., 2007). Örneğin kuvvet antremanı öncesinde amino asit veya protein alımı pozitif azot dengesini geliştirerek antremanı kolaylaştırır (Rodriguez et al., 2007) veya direnç antremanının hemen sonrasında 20 gr iyi kalite protein almak protein sentezini teşvik eder (Moore et al., 2009). Kan şekerini uzun süreli korumak için iftarda karbonhiratdan zengin besinlerin bulunmasına dikkat edilmeli (karaciğer ve kas glikojen depolarının azami şekilde dolması için), sahurda ise midenin geç boşalması ve açlık hissinin bastırılması için yağ oranı yüksek gıdalar tercih edilmelidir. Başka bir taktik ise yarışmadan önce aktivitenin azaltılması ve böylece kan şekerinin düşmesinin engellenmesidir (Shephard, 2012).

Ramazan ayında bir diğer sorun sıvı kaybıdır. Özellikle sıcak ve nemli havalarda yapılan ultra-dayanıklılık yarışmalarında ciddi dehidratasyon görülür. Sahurda sıvı ve tuz almak, yarışma öncesi aktiviteyi azaltmak, güneşten korunmak ve vücudu soğuk tutarak terlemeyi önlemek dehidratasyonu azaltabilir (Shephard, 2012). 
Açlıkta, karaciğerdeki glikojen depoları hızlı bir şekilde (24 saat) tüketilir ve glikoneojenez uyarılır. Açlığın erken döneminde depo yağlar ve proteinler enerji için kullanılır. Enerji için önce yağsız kas dokusu sonra visseral proteinler kullanılır. Proteinler dolaylı olarak glikoneojenezden, doğrudan ise periferal kas depolarındaki dallı zincirli amino asitlerden enerjiye çevrilir (Baysal et al., 2002). Vücut proteinlerinin yaklaşık yarısı kullanıldığında ise ölüm gerçekleşir (Guyton \& Hall, 2007).

Dayanıklılık egzersizi gibi aerobik olarak yapılan aktiviteler sırasında vücuttaki karbonhidrat depoları tükenir çünkü kaslar kasıldığında kas glikojeni ve kan glikozu hızla azalır. Eğer egzersiz açlık durumunda uzun süreli devam ederse karbonhidrat depolarının azalmasıyla yă̆ mobilizasyonu artar kas kasılması için gerekli enerji yağlardan sağlanır ve az miktarda kalan karbonhidrat beynin ve eritrositlerin faaliyetleri için kullanılır (Stannard, 2003).

Açlık ve uzun süreli egzersizin her ikisi de metabolik ihtiyaçları karşılamak için yağ asitlerinin mobilizasyonu ve oksidasyonu arttırır (Stannard, 2011).

Ramazan ayı gibi aralıklı açlık durumlarında, sporcu uyku düzenine ve antreman programına dikkat ederse anaerobik egzersiz performansı değişmez. Antremanda yorgunluk görülüyorsa uyku düzeni bozukluğundan veya gıda alımındaki eksiklikten kaynaklanmaktadır (Shephard, 2012).

Oruç tutan sporcularda, ortalama on dakikalık aerobik egzersiz sırasında maksimal oksijen tüketiminde bozulma görülmemektedir. Ancak egzersiz süresi uzadı̆̆ında performansta ufak bozulmalar görülmektedir. Bunun sebebi zayıf motivasyon, glikojen depolarının tükenmesi veya susuzluk olabilir (Shephard, 2012).

Ramazan ayı sporcular için birtakım zorluklar içerir. Bu zorluklar sadece sıvı ve gıda alımı eksikliği değil aynı zamanda uyku eksikliğini de içermektedir. Uyku saatindeki değişiklik sonucu sirkadiyen ritm değişikliği, hormonal ve gastrointestinal fonksiyonlarda değişim görülmektedir (Waterhouse, 2010). Ramazan ayının egzersiz performansı üzerine etkileri belirsizdir ve ileride yapılacak olan geniş ölçekli çalışmalara ihtiyaç vardır.

\section{KAYNAKLAR}

Aksoy, M. (2000). Beslenme Biyokimyası, Ankara: Hatipoğlu Basım ve Yayın Ltd. Şti, s. 591-599.

Altun, G., Akansu, B., Altun, BU., Azmak, D., Y1lmaz A. (2004). Deaths due to hunger strike: post-mortem findings. Forensic Sci Int, 146(1), 35-38.

Arkinstall, MJ., Bruce, CR., Nikolopoulos, V., Garnham, AP., Hawley, JA (2001). Effect of carbonhydrate ingestion on metabolism during running and cycling. J Apll Physiol, 91(5), 2125-2134.

Atkinson, G., Edwards, B., Reilly, T., Waterhouse, J. (2007). Exercise as a synchroniser of human circadian rhythms: an update and discussion of the methodological problems. Eur J Appl Physiol, 99(4), 331341.

Aziz, AR., Wahid, MF., Png, W., Jesuvadian, CV. (2010). Effects of ramadan fasting on 60 min endurance running performance in moderately trained men. Br J Sport Med, 44(7), 516-521.

Bahammam, A. (2006). Does ramadan fasting affect sleep. Int J Clin Pract, 60(12), 1631-1637. 
Barendregt, K., Soeters, P., Allison, S., Sobotka, L. (2008). Basics in clinical nutrition: Simple and stres starvation. Eur e-J Clin Nutr Metab, 3, p. 267-271.

Baysal, A. (2004). Beslenme. 10. Bask1, Ankara: Hatipoğlu Yayınevi, s. 33-442.

Baysal, A., Bozkurt, N., Pekcan, G., Besler, T., Aksoy, M. et al. (2002). Diyet El Kitabı. 4. Baskı, Ankara: Hatipoğlu Yayınevi, s. 371-372.

Bellisle, F., Mcdevitt, R., Prentice, AM (1997). Meal frequency and energy balance. Brt journal of Nutr, 77(1) 57-70.

Bogdan, A., Bouchareb, B., Touitou, Y. (2005). Response of circulating leptin to ramadan day-time fasting: a circadian study. Brt Journal of Nutr, 93(4) 515-518.

Bogdan, A., Bouchareb, B., Touitou, Y. (2001). Ramadan fasting alters endocrine and neuroendocrine circadian patterns. Life Sci, 68(14), 1607-1615.

Bozinovski, NC., Belissimo, N., Thomas, SG., Pencharz, PB., Goode RC. et al. (2009). The effect of duration of exercise at the ventilation thresold on subjective apetite and short term food intake in 9 to 14 year old boys and girls. Int Journal of Behavioral Nutrition and Physical Activity, 6 (1), 66.

Briswalter, J., Bouhlel, E., Falola, JM., Abbis, CR., Vallier, JM. et al. (2011). Effects of ramadan intermittent fasting on middle distance running performance in well trained runners. Clin J Sport Med, 21(5), 422427.

Broom, DR., Batherham, RL., King, JA., Stensel, DJ. (2008). İnfluence of resistance and aerobic exercise on hunger, circulating levels of acylated ghrelin and peptid YY in healthy males. Am J Physiol, 296(1), 29-35.

Burke, L. (2010). Fasting and recovery from exercise. Br J Sports Med, 44(7), 502-508.

Burke, LM., Angus, DJ., Cox, GR., Cummings, NK., Febrario, AM. et al. (2000). Effect of fat adaptation and carbonhydrate restoration on metabolism performance during prolonged cycle. J Appl Physiol, 89(6), 2413- 2421.

Chaouachi, A., Coutts, AJ., Chamari, K., Wong, DP., Chaouachi, M. et al. (2009). Effect of ramadan intermittent fasting on aerobic and anaerobic performance and perception on fatique in male elite judo athletes. J Strength Cond Res, 23(9), 2702-2709.

Chtourou, H., Hammouda, O., Souissi, H., Chamari, K., Chaouachi, A. et al. (2011). The effect of ramadan fasting on physical performances, mood state and perceived exertion in young footballers. Asian Journal of Sport Med, 2(3), 177-185.

Cox, GR., Clark, SA., Cox, AJ., Halson, SL., Hargreaves, M. et al. (2010). Daily training with high carbonhydrate availability increases exogenous carbonhydrate oxidation during endurance cyling. $J$ Appl Physiol, 109(1), 126-134.

Coyle, EF. (2004). Fluid and fuel intake during exercise. Journal of Sports Sci, 22(1), 39-55.

De Bock, K., Richter, AE., Russell, AP., Eijnde, BO., Derave, W. et al. (2005) Exercise in fasted state facilitates fibre type-spesific intramyocellular lipid breakdown and stimulates glycogen resynthesis in humans. $J$ Physiol, 564(2), 649-660.

De Bock, K., Derave, W., Ramaekers, M., Richter, AE., Hespel, P. (2007). Fiber type spesific muscle glycogen sparing due to carbonhydrate intake before and during exercise. J Apll Physiol, 102(1), 183-188.

De Bock, K., Derave, W., Eijnde, BO., Hesselink, MK., Koninckx, E. et al. (2008). Effect of training fasted state on metabolic responses during exercise with carbonhydrate intake. J Apll Physiol, 104(4), 10451055 . 
Dupont, G., Defontaine, M., Bosquet, L., Blondel, N., Moalla, W. et al. (2010). Yo-Yo intermittent recovery test versus the universite de Montreal trrack test: relation with a high-intensity intermittent exercise. $J$ Sci Med Sport, 13(1), 146- 150.

Fallah, J. (2010). Ramadan fasting and exercise performance. Asian Journal of Sport Med, 3(1), 130-131.

Faye, J., Fall, A., Badji, L., Cisse, W., Stephan, F. et al. (2005). Effects of ramadan fast on weight, performance and glycemia during training for resistance. Dakar Med, 50(3), 146-151.

Febbario, MA., Chui, A., Angus, DJ., Arkinsstall, MJ., Hawley, JA. (2000). Effect of carbonhydrate ingestion before and during exercise on glucose kinetics and performance. J Apll Physiol, 89(6), 2220- 2226.

Guyton ve Hall. (2007). Tıbbi Fizyoloji. Çavuşoğlu H (Ed). Diyetteki dengeler; beslenmenin düzenlenmesi; şişmanlık ve açlık; vitaminler ve mineraller. Nobel Tıp Kitapevleri, 11.Baskı, Ünite 8, Bölüm 71: s. 867- 880 .

Gariballa, S. (2008). Refeeding syndrome: a potantially fatal condition but remains underdiagnosed and undertreated. Nutrition, 24(6), 604-606.

Hawley, JA., Gibala, MJ., Bermon, S. (2007). Innovations in athletic preparation: role of substrate availability to modify training adaptation and performance. J Sport Sci, 25(1), 115-124.

Horowitz, JF., Rodriguez, RM., Byerley, LO., Coyle, EF. (1997). Lipolytic suppression following carbonhydrate ingestion limits fat oxidation during exercise. Am J Physiol, 273(1), 768-775.

İmai, İS. (2009). SIRT1 and caloric restriction: an insight into possible trade-offs between robustness and frailty. Curr Opin Clin Nutr Metab Care, 12(4), 350-356.

İvy, JL., Kuo, CH. (1998). Regulation of GLUT4 protein and glycogen synthase during muscle glycogen synthesis after exercise. Acta Physiol Scand, 162(3), 295- 304.

Karlı, U., Güvenç, A., Aslan, A., Hazır, T., Acıkada. C. (2007). İnfluence of ramadan fasting on anaerobic performance and recovery from short high intensity exercise. J Sport Sci Med, 6(4), 490- 497.

Kassab, S., Ghaffar, TA., Nagalla, DS., Sachdeva, U., Nayar, U. (2003). Serum leptin and insulin levels during chronic duirnal fasting. Asia Pasific J Clin Nutr, 12(4), 483-487.

Kirkendall, DT., Leiper, JP., Bartagi, Z., Dvorak, J., Zerguini, Y. (2008). The influence of ramadan on physical performance measures in young muslim footballers. J Sport Sci, 26(3), $15-27$.

Kraft, MD., Btaiche, IF., Sacks, GS. (2005). Rewiev of the refeeding syndrome. Nutr Clin Pract, 20(6), 625633.

Larijani, B., Zahedi, F., Sanjari, M., Amini, M., Jalili, MB. et al. (2003). The effect of ramadan fasting on fasting serum glucose in healthly adults. Med J Malaysia, 58(5), 678-680.

Mansi, KM. (2007). Study the effects of ramadan fasting on the serum glucose and lipid profile among healthy jordanian students. American Journal of Apll Sci, 4(8), 565-569.

Maughan, RJ., Fallah, J., Coyle, EF. (2010). The effects of fasting on metabolism and performance. Br J Sports Med, 44(7), 490-494.

Maughan, RJ., Bartagi, Z., Dvorak, J., Zerguini, Y. (2008). Dietary intake and body composition of football players during the holy month of ramadan. J Sports Sci, 26(3), 29-38.

Maughan, RJ., Leiper, JB., Bartagi, Z., Zrifi, R., Zerguini, Y. et al. (2008). Effect of ramadan fasting on some biochemical and hematological parameters in tunusian youth soccer players undertaking their usual training and competition schedule. J Sport Sci,26(3), 39-46.

Matson, MP., Wan, R. (2005). Benefical effects of intermittent fasting and caloric restriction on the cardiovascular and cerebrovascular system. J Nutr Biochem, 16(3), 129-137. 
Mcardle, WD., Katch, FI., Katch, WL. (2007). Exercise Physiology: Energy, nutrition and human performance. Sixth edition. USA: Lippincott Willams and Wilkins, 3, s. 82-107.

Mcdonald, RS., Smith, RJ. (2001). Starvation. Becker KL (Ed). Principles and practice of endocrinology and metabolism. 3 rd ed. Philadelphia: Lippincott Willams and Wilkins, s. 1247- 1251.

Meckel, Y., Ismeal, A., Eliakim, A. (2008). The effect of ramadan fast on pyhsical performance and dietary habits in adolescent soccer players. J Sports Sci, 102, 651- 657.

Minet-Ringuet, J., Le Ruyet, PM., Tome, D., Even, PC. (2004). A tryptophan-rich protein diet efficiently restores sleep after food deprivation in the rat. Behav Brain Res, 152(2), 335-340.

Moore. DR., Meghann, JR., Jessica, LF., Jason, ET., Elisa, IG. et al. (2009). Ingested protein dose response of muscle albumin protein synthesis after resistance exercise in young man. Am J Clin Nutr, 89(1), 161168.

Ramadan, J. (2002). Does fasting during ramadan alter body composition, blood constituents and physical performance. Med Principles Pract, 11(2), 41-46.

Ramadan, J., Telahoun, G., Al-Zaid, NS., Barac-Nieto, M. (1999). Responses to exercise, fluid, and energy balances during Ramadan in sedentary and active males. Nutrition, 15(10), 735-739.

Reily, T., Waterhouse, J. (2009). Sport performance: is there evidence that the body clock plays a role. Eur J Appl Physiol, 106(3), 321-332.

Reily, T., Waterhouse, J. (2007). Altered sleep-wake cycles and food intake: the ramadan model. Physiol Behav, 90(2-3), 219-228.

Rodriguez, NR., Di Marco, NM., Langley, S. (2009). American college of sport medicine position stand: Nutrition and athletic performance. Med Sci Sports Exerc, 41(3), 709-731.

Rodriguez, NR., Vislocky, LM., Gaine, PC. (2007). Dietary protein, endurance exercise and human skeletal muscle protein turnover. Curr Opin Clin Nutr Metab Care, 10(1), 40-45.

Roky, R., Houti, L., Moussamih, S., Potbi, S., Aadil, N. (2004). Physiological and chronobiological changes during ramadan intermittent fasting. Ann Nutr Metab, 48(4), 296-303.

Roy, J., Hwa, OC., Singh, R., Aziz, AR., Jin, CW. (2011). Self-generated coping strategies among muslim athletes during ramadan fasting. Journal of Sport Sci and Med, 10(1), 137-144.

Senhadji, MY., El Kebir, B., Belleville, J., Bouchenak, M. (2009). Assesment of dietary consumption and timecourse of changes in serum lipids and lipoproteins before, during and after ramadan in young algerian adults. Singopore Med J, 50(3), 238-244.

Shiffers, SM., Maughan, RJ. (2008). Water and salt balance in young male football players in training during the holy mouth of ramadan. J Sport Sci, 26(3), 47-54.

Shephard, RJ. (2012). The impact of ramadan of observance upon athletic performance. Nutrients, 4(6), 491505 .

Siddugui, QA., Sabir, S., Subhan, MM. (2005). The effect of ramadan fasting on spirometry in healthy subjects. Respirology, 10(4), 525-528.

Singh, R., Ooi, CH., Roy, C., Jin, CW., İsmael, MJ. et al. (2011). Subjective perception of sport performance, training, sleep and dietary patterns of malaysian junior muslim athletes during intermittent ramadan fasting. Asian Journal Sport Med, 2(3), 167-173.

Souissi, N., Souissi, H., Sahli, S., Tabka, Z., Dogui, M. et al. (2007). Effect of ramadan on the diurnal variation in short-term high power output. Chronobiol Int, 24(5), 991- 1007.

Splinder, SR. (2010). Caloric restriction: from soup to nuts. Ageing research rewievs, 9(3), 324-353. 
Stannard, SR., Johnson, NA. (2003). İnsulin resistance and elevated triglyceride in muscle: more important for survival than thrifity genes. J Physiol, 554(3), 595- 607.

Stannard, SR. (2011). Ramadan and its effect on fuel selection during exercise and following exercise training. Asian Journal of Sport Med, 2(3), 127-133.

Stannard, SR., Thompson, MW. (2008). The effect of participation in ramadan on substrate selection during submaximal cycling exercise. J Sci Med Sport, 11(5), 510-517.

Tian, HH., Aziz, AR., Png, W., Wahid, MF., Yeo, D. et al. (2011). Effects of fasting during ramadan mouth on cognitive function in muslim athletes. Asian Journal of Sport Med, 2(3), 145-153.

Trabelsi, K., Abed, K., Treponovski, JF., Stannard, SR., Ghlissi, Z. et al. (2011). Effects of ramadan fasting on biochemical and anthropometric parameters in physical active men. Asian Journal of Sport Med, 2(3), 134-144.

Treponowski, JF., Bloomer, RJ. (2010). The impact of religious fasting on human health. Nutrition Journal, doi: $10.1186 / 1475-2891-9-57$

Tresley, J., Sheean, PM. (2008). Refeeding syndrome: recognition is the key to prevention and management. $J$ Am Diet As, 108(12), 2105- 2108.

Vaguero, A., Reinberg, D. (2009). Calorie restriction and the exercise of chromatin. Gene and Development, 23(16), 1849- 1869.

Varady, KA., Hellerstein, MK. (2007). Altarnate day fasting and chronic disease prevention: a review of the human and animal trials. Am J Clin Nutr, 86(1), 7-13.

Waterhouse, J. (2010). Effect of ramadan on physical performance: chronobiological consederations. Br J Sport Med, 44(7), 509-515.

Waterhouse, J., Alkib, L., Edwards B. (2008). Diurnal changes in sleep, food and activity during ramadan 2006, in the UK: some preliminary observations. Biol Rhtym Res, 39(6), 449-467.

Wilson, D., Drust, B., Reily, T. (2009). İs diurnal lifestyle altered during ramadan in professiona Muslim athletes?. Biological Rhytm Research, 40(5), 385- 397.

Zerguini, Y., Dvorak, J., Maughan, RJ., Leiper, JB., Bartagi, Z. et al. (2008). İnfluence of ramadan fasting on physiological and performance variables in football players. J Sport Sci, 26(3), 3-6.

Zerguini, Y., Kirkendall, D., Junge, A., Dvorak, J. (2007). İmpact of ramadan physical performance in professional soccer players. Br J Sport Med, 41(6), 398- 400. 